\title{
Antidiarrhoea and toxicological evaluation of the leaf extract of Dissotis rotundifolia triana (Melastomataceae)
}

\author{
Tavs A Abere ${ }^{1 *}$, Pius E Okoto², Freddy O Agoreyo ${ }^{3}$
}

\begin{abstract}
Background: The leaves of Dissotis rotundifolia are used ethnomedically across Africa without scientific basis or safety concerns. Determination of its phytochemical constituents, antimicrobial activity, effects on the gastrointestinal tract (GIT) as well as toxicological profile will provide supportive scientific evidence in favour of its continous usage.

Method: Chemical and chromatographic tests were employed in phytochemical investigations. Inhibitory activity against clinical strains of Escherichia coli, Pseudomonas aeruginosa, Staphylococcus aureus and Salmonella typhi were compared with Gentamycin. Our report includes minimum inhibitory concentration (MIC) against the tested organisms. The effect of the ethanol extract on the motility of the GIT in mice using the charcoal plug method and castor oil induced diarrhoea in rats was evaluated. Toxicological evaluation was determined by administering $250 \mathrm{mg} / \mathrm{kg}$ and $500 \mathrm{mg} / \mathrm{kg}$ of extracts on male Wistar rats for 14 days with normal saline as control. The tissues of the kidneys, liver, heart and testes were examined.

Results: Phytochemical studies revealed the presence of alkaloids, saponin and cardiac glycosides. The crude ethanol extract and fractions inhibited the growth of E. coli, P. aeruginosa, S. aureus and S. typhi to varying extents. The degree of transition exhibited by the charcoal meal was dose-dependent. In the castor oil induced diarrhoea test, all the doses showed anti-spasmodic effects. The LD50 in mice was above $500 \mathrm{mg} / \mathrm{kg}$ body weight. Toxicological evaluation at $500 \mathrm{mg} / \mathrm{kg}$ showed increased cytoplasmic eosinophilia and densely stained nuclei of the liver, tubular necrosis of the kidney, presence of ill-defined testes with indistinct cell outlines and no remarkable changes in the heart.
\end{abstract}

Conclusion: Ethanol extracts of Dissotis rotundifolia have demonstrated antimicrobial activity against clinical strains of selected microorganisms. The plant showed potential for application in the treatment of diarrhoea, thereby justifying its usage across Africa. It also demonstrated toxicity in certain organs at the dose of $500 \mathrm{mg} / \mathrm{kg}$, and it will be necessary to fully establish its safety profile.

\section{Background}

Medicinal plants are commonly used in treating and preventing specific ailments and diseases, and are generally considered to play a beneficial role in healthcare. They are already important to the global economy. Demand is steadily increasing not only in developing countries but also in the industrialized nations [1]. World Health Organisation (WHO) estimates that

\footnotetext{
* Correspondence: eseabere@yahoo.com

'Department of Pharmacognosy, Faculty of Pharmacy, University of Benin, Benin City. Nigeria

Full list of author information is available at the end of the article
}

approximately $80 \%$ of the developing world's population meets their Primary Healthcare needs through traditional medicine [2]. About 25\% of prescription drugs dispensed in the United States contain at least one active ingredient derived from plant material. Some are made from plant extracts while others are synthesized to mimic a natural plant compound [3]. It has been estimated that one out of every three people in the United States had tried at least one form of alternative medicine [4]. A follow up study reported that the number of respondents using alternative therapies increased from $33.8 \%$ in 1990 to $42.7 \%$ in 1997 [5]. Within the last few 
decades, many plants have been screened for their biological and pharmacological properties by researchers. These efforts are continually being taken to examine the merits of traditional medicine in the light of modern science with a view aimed at adopting effectively beneficial medical practice and discouraging harmful ones [6].

The genus Dissotis comprises of 140 species native to Africa [7]. Dissotis rotundifolia Triana, a native of tropical West Africa belongs to the Melastomataceae family [8] and common names include Pinklady (English), Awede (Yoruba) and Ebafo (Bini) [9].

Dissotis rotundifolia is a versatile perennial slender creeping herb with prostate or ascending stems up to 40 $\mathrm{cm}$ high, rooting at the nodes and producing from seeds and stolon. The leaves are ovate to ovate-lanceolate or suborbicular, 1.5-7.0 cm long, 0.8-4.0 cm wide, 3-nerved, both surfaces sparsely to densely pilose, margins ciliate and somewhat crenuate, apex acute, base truncate to short-attenuate, petioles $0.5-2.5 \mathrm{~cm}$ long [10].

In Nigeria, $D$. rotundifolia is used mainly for the treatment of rheumatism and painful swellings. The leaves decoction is used to relieve stomach ache, diarrhea, dysentery, cough, stop abortion, conjunctivitis, circulatory problems and venereal diseases [9]. It is used in East Africa for the treatment of bilharzias [11] and in Cameroun, the leaves are used for dysentery [12]. In tropical Africa, the whole plant is used as a remedy for rheumatism and yaws and as an antihelmintic and in Liberia for diarrhea [13]. Hot water extract of Dissotis rotundifolia given orally is used for hookworm infestations [11].

\section{Methods}

\section{Plant collection and authentication}

The leaves of Dissotis rotundifolia Triana were collected in Ugbowo area of Benin City, Edo State, Nigeria. The plants were identified and confirmed by the plant curator at the Forest Research Institute of Nigeria (FRIN), Ibadan where voucher specimens were deposited with the number, FIH 107850. The leaves were air-dried and powdered on an electric mill.

\section{Phytochemical studies}

Chemical and Chromatographic tests were employed in the preliminary Phytochemical screening for various secondary metabolites such as Tannins (phenazone; iron complex; formaldehyde and modified iron complex tests), Alkaloids (Mayer's; Dragendorff's, Wagner's and 1\% picric acid reagents), Cardiac glycosides (Keller Killiani, Lieberman, Legal and Kedde tests), Saponin glycosides (frothing and haemolysis tests), Anthracene derivatives (Borntrager's test for combined and free anthraquinones) and Cyanogenetic glycosides (sodium picrate paper test) [14-17]. Thin layer chromatography of aqueous ethanol extract containing $10 \% \mathrm{H}_{2} \mathrm{SO}_{4}$, shaken with chloroform and free alkaloids precipitated by the addition of excess ammonia and extracted with chloroform, on silica gel-G, activated by heating at $110^{\circ} \mathrm{C}$ for 30 minutes was developed with the solvent system Methanol : chloroform (3: 7). Chromatoplates were viewed under the UV light and sprayed with Dragendorff's spray reagent and $R_{f}$ values calculated. Paper chromatography of the aqueous ethanol extract, using ascending method and Whatman No. $3 \mathrm{~mm}$ was developed with the solvent system n-butanol: water: acetic acid (4: $1: 5)$, examined both in daylight and under UV light at $25 \mathrm{~nm}$, sprayed with ferric chloride until colours developed and $R_{f}$ values calculated.

\section{Antidiarrhoea evaluation Organisms}

The organisms used were clinical isolates of Escherichia coli, Pseudomonas aeruginosa, Staphylococcus aureus and Streptococcus faecalis obtained from patients in the University of Benin Teaching Hospital, Benin City.

\section{Animals}

Swiss albino mice of both sexes $(26.87 \pm 1.64 \mathrm{~g})$ and male Wistar rats $(207 \pm 17.94 \mathrm{~g})$ were obtained from the Animal House of Pharmacology Department, Faculty of Pharmacy, University of Benin, Benin City. All the animals were kept under standard environmental conditions and were handled according to international protocol for use of animals in experiments. They had free access to food and water i. e. they were fed with standard pellets and tap water ad libitum. Permission and approval for animal studies were obtained from the College of Medical Sciences Animal Ethics Committee, University of Benin, Benin City with ADM/F. 22 A/VOL. $\mathrm{VIII} / 349$.

\section{Intestinal transit test}

The mice used for this test were starved for $24 \mathrm{hrs}$ prior to the experiment but allowed access to water. They were divided into 7 groups of 5 each. Mice in groups A, $\mathrm{B}, \mathrm{C}$ and $\mathrm{D}$ were administered with $100,200,300$ and $400 \mathrm{mg} / \mathrm{kg}$ extract, the fifth group $5 \mathrm{ml} / \mathrm{kg}$ normal saline (vehicle for the reconstitution of the extract), sixth group $2.5 \mathrm{mg} / \mathrm{kg}$ Atropine sulphate (Adrich. Chem. Co. UK) all by the intraperitoneal route. The seventh group received $0.5 \mathrm{mg} / \mathrm{kg}$ Carbachol. After 30 minutes, they were fed through the gastric tube with $0.5 \mathrm{ml}$ of freshly prepared charcoal meal (10\% charcoal in acacia gum). The mice were sacrificed 20 minutes later by cervical dislocation and gastrointestinal tract removed. The distance travelled by the charcoal meal from the pylorus was measured and expressed as the percentage of the total length of the small intestine extending from the 
gastropyloric to the ileocaecal junction [18]. The intestinal motility was derived from the equation.

$$
\% \text { motility }=\frac{\text { Distance traveled by the meal }}{\text { Total length of small intestine }} \times 100
$$

\section{Castor oil induced diarrhoea}

Rats for this test were first observed for any wet faeces/ droppings (their somewhat rounded or irregular shape, soft consistency and the presence of a brown stain surrounding each faeces on the filter paper). They were easily distinguished from the normal dry faeces which were elongated, regular in shape, hard and did not stain the filter paper. Those that produced wet droppings were not used for the test.

Diarrhoea was induced by oral administration of castor oil $\left(0.5 \mathrm{ml} \mathrm{rat}^{-1}\right)$ to overnight fasted rats. Dissotis rotundifolia extract $(100-400 \mathrm{mg} / \mathrm{kg}$ ) or vehicle (normal saline) or reference (loperamide) were given intraperitoneally 60 minutes before cathartic administration.

Two hours after dosing with castor oil, the individual rat cages were inspected for the presence of wet faeces, their absence was recorded as a positive result, indicating protection from diarrhoea at that time [19].

\section{Preliminary antimicrobial screening}

Powdered leaf material (2 kg) of Dissotis rotundifolia Triana was extracted with $50 \%$ aqueous ethanol at room temperature. After $48 \mathrm{~h}$, the extract was clarified by filtration and evaporated to dryness in vacuo. Residues were collected and evaluated against the four test organisms at $100 \mathrm{mg} / \mathrm{mL}$ in $50 \%$ aqueous methanol.

\section{Activity guided fractionation of Dissotis rotundifolia}

The aqueous ethanolic extract (8 g) of Dissotis rotundifolia was partitioned between water and chloroform. The fractions were evaporated to dryness in vacuo. Partitioning using water: ethylacetate and water: butanol were similarly carried out respectively. The resulting fractions were evaluated against the test organisms at $100 \mathrm{mg} / \mathrm{mL}$ in aqueous methanol.

\section{Antimicrobial test}

The well diffusion method was used for the antimicrobial screening against the four test organisms, following standard procedures with nutrient agar as medium.

The minimum inhibitory concentration (MIC), the lowest concentration of a compound that inhibits growth of a microorganism, was determined by the standard two-fold dilution technique using nutrient broth medium [20].

\section{Toxicological evaluation \\ Acute toxicity test}

Swiss albino mice (5 animals per group) were orally treated with the aqueous ethanol extract of Dissotis rotundifolia at doses of $1 \mathrm{~g} / \mathrm{kg}, 2 \mathrm{~g} / \mathrm{kg}, 3 \mathrm{~g} / \mathrm{kg}, 4 \mathrm{~g} / \mathrm{kg}$ and $5 \mathrm{~g} / \mathrm{kg}$. The control group received only the vehicle (normal saline). Each group of mice was placed in the test cage for a 30 -min habituation period before any oral administration of the drug using an orogastric syringe. The animals were observed for 3 days. Lethality and gross toxicological features were recorded for each group at the end of the period [21]. The animals were further observed for fourteen days.

\section{Sub-acute toxicity test}

Thirty male Wistar rats were randomly distributed into three groups of ten rats each. The first (A) group served as control and received $5 \mathrm{ml}$ of normal saline (vehicle) while the second (B) and third (C) groups received 250 $\mathrm{mg} / \mathrm{kg}$ and $500 \mathrm{mg} / \mathrm{kg}$ per day of $D$. rotundifolia extract respectively orally for 14 consecutive days. The animals were observed for signs of toxicity (abnormal behaviours, writhing convulsion, mood, motor activity and general body conditions). At the end of 14 days, the rats were sacrificed under chloroform anesthesia. The livers, kidneys, hearts and testes were removed and preserved in $10 \%$ formaldehyde. Tissues from each organ were sectioned (6 microns $(\mu)$ thick) in paraffin wax and stained with hematoxylin and eosin (H \& E) for assessment of tissue morphology [22].

\section{Results}

Phytochemical screening of the leaves of Dissotis rotundifolia revealed the presence of alkaloids, tannins, saponins and cardiac glycosides (Table 1). Chromatographic fingerprints were established using Thin-layer and Paper chromatographic techniques (Table 2), detecting with Dragendorff and Ferric chloride for the presence of alkaloids and phenolic compounds respectively.

Aqueous ethanol extract of $D$. rotundifolia showed antimicrobial activity against the tested organisms (Table 3). The activities of the various fractions as well as the minimum inhibitory concentration (MIC) of the aqueous ethanol extract are presented in Tables 4 and 5 respectively. The effects of the ethanol extract on GIT motility (Table 6) showed a reduction in percentage movement of charcoal plug in a dose dependent manner. In the castor oil induced diarrhea experiment (Table 7), the concentrations of the ethanol extract used as well as the reference standard, Loperamide did not produce any wet faeces.

\section{Acute toxicity profile}

In the acute toxicity study, the aqueous extract of $D$. rotundifolia did not produce any mortality up to the oral dose level of $5 \mathrm{~g} / \mathrm{kg}$ body weight in mice, hence the LD50 was indeterminable. There were no significant changes in the behaviour in relation to the posture, diarrhoea, mood and motor activity. The animals did not convulse nor exhibited writhings. However, in the subacute toxicity test (Table 8 ), there were clear evidence 
Table 1 Results of preliminary phytochemical screening of Dissotis rotundifolia leaves

\begin{tabular}{|c|c|}
\hline Secondary metabolites & \\
\hline Alkaloids & \\
\hline Dragendorf's reagent & + \\
\hline Wagner's reagent & + \\
\hline Mayer's reagent & + \\
\hline $1 \%$ picric acid reagent & + \\
\hline Anthracene derivatives & \\
\hline Combined anthraquinones & - \\
\hline Free anthraquinones & - \\
\hline Tannins & \\
\hline Phenazone test & + \\
\hline Iron complex test & + \\
\hline Formaldehyde test & + \\
\hline Modified iron complex test & + \\
\hline Saponin glycosides & \\
\hline Frothing test & + \\
\hline Haemolysis test & + \\
\hline Cardiac glycosides & \\
\hline Keller killiani test & + \\
\hline Lieberman's test & + \\
\hline Legal test & + \\
\hline Kedde test & + \\
\hline Cyanogenetic glycosides & \\
\hline Sodium picrate test paper & - \\
\hline
\end{tabular}

of histopathological effects in most of the organs, especially at the dose of $500 \mathrm{mg} / \mathrm{kg}$.

\section{Discussion}

The need for phytochemical screening has become imperative, since many plants accumulate biologically
Table 3 Antimicrobial screening of Dissotis rotundifolia leaves at $100 \mathrm{mg} / \mathrm{mL}$, in methanol: water (1: 1)

\begin{tabular}{lccc}
\hline Test organism & $\begin{array}{c}\text { Aq. ethanol extract } \\
\text { of } \mathbf{D} \text {. rotundifolia } \\
(\mathbf{m m})\end{array}$ & $\begin{array}{c}\text { Gentamycin } \\
(\mathbf{1 0} \mathbf{\mu g} / \mathbf{m l}) \\
(\mathbf{m m})\end{array}$ & $\begin{array}{c}\text { Solvent Aq. } \\
\text { methanol } \\
(\mathbf{m m})\end{array}$ \\
\hline $\begin{array}{l}\text { Escherichia coli } \\
\begin{array}{l}\text { Pseudomonas } \\
\text { aeruginosa }\end{array}\end{array}$ & 8 & 13 & 0 \\
$\begin{array}{l}\text { Staphylococcus } \\
\text { aureus }\end{array}$ & 11 & 15 & 0 \\
$\begin{array}{l}\text { Salmonella } \\
\text { typhi }\end{array}$ & 8 & 14 & 0 \\
\hline
\end{tabular}

The diameter recorded is the diameter of the zone of inhibition less the diameter of the cup $(8 \mathrm{~mm})$.

Values are mean $(n=5)$.

active, complex organic chemicals (secondary plant metabolites) in their tissues. Dissotis rotundifolia revealed the presence of alkaloids, saponins and cardiac glycosides. Typical alkaloids often have marked pharmacological effects when administered to man and other animals, thus their presence is of particular interest [17]. The pharmacological effectiveness of glycosides is dependent on the aglycones, but the sugars render the compounds more soluble and increase the power of fixation of the glycosides. Plants containing alkaloids and/or glycosides have been known to possess antidiarrhoeal activities, amongst which are Ageratum conyzoides and Vernonia cinerea [23]. It could therefore be suggested that the secondary plant metabolites present in $D$. rotundifolia are responsible for the biological activities observed.

Most diarrhoeas are known to be infective in origin and there is therefore a role for anti-infective agents in the management of such diarrhoeas [23]. Among other possible causative microorganisms implicated in diarrhoea, the role of enteroaggregative Escherichia coli has been reported [24]. The aqueous ethanol extract alongside the partitioned fractions were subjected to antibacterial test at $100 \mathrm{mg} / \mathrm{ml}$ so as to locate the fraction with the highest activity. The results indicated that the

Table 2 Chromatographic results

\begin{tabular}{|c|c|c|c|c|c|c|}
\hline \multicolumn{7}{|c|}{ Thin layer chromatography } \\
\hline Extract & Solvent System & $\begin{array}{l}\text { No. of } \\
\text { spots }\end{array}$ & $\begin{array}{l}\text { Colour in } \\
\text { Daylight }\end{array}$ & Colour in UV & $\begin{array}{l}\text { Colour after spraying with } \\
\text { Dragendorff }\end{array}$ & $\begin{array}{l}R_{f} \\
\text { value }\end{array}$ \\
\hline \multirow[t]{2}{*}{$\begin{array}{l}\text { Aqueous } \\
\text { ethanol }\end{array}$} & Methanol: chloroform $(3: 7)$ & 2 & Colourless & $\begin{array}{l}\text { Light green } \\
\text { fluorescent }\end{array}$ & Reddish brown & 0.78 \\
\hline & & & colourless & $\begin{array}{l}\text { Light green } \\
\text { fluorescent }\end{array}$ & Reddish brown & 0.80 \\
\hline \multicolumn{7}{|c|}{ Paper chromatography } \\
\hline Extract & Solvent System & $\begin{array}{l}\text { No. of } \\
\text { spots }\end{array}$ & $\begin{array}{l}\text { Colour in } \\
\text { daylight }\end{array}$ & Colour in UV & $\begin{array}{l}\text { Colour after spraying with ferric } \\
\text { chloride }\end{array}$ & $\begin{array}{l}R_{f} \\
\text { value }\end{array}$ \\
\hline $\begin{array}{l}\text { Aqueous } \\
\text { ethanol }\end{array}$ & $\begin{array}{l}\text { N-butanol: water: acetic acid } \\
(4: 1: 5)\end{array}$ & 1 & Colourless & green fluorescent & Blue black colour & 0.21 \\
\hline
\end{tabular}


Table 4 Antimicrobial screening of three fractions of $D$. rotundifolia extract at $100 \mathrm{mg} / \mathrm{MI}$, in methanol: water (1: 1).

\begin{tabular}{lcccc}
\hline Test organism & $\begin{array}{c}\text { Chloroform } \\
\text { fraction } \\
\text { (mm) }\end{array}$ & $\begin{array}{c}\text { Ethylacetate } \\
\text { fraction } \\
\text { (mm) }\end{array}$ & $\begin{array}{c}\text { Butanol } \\
\text { fraction } \\
\text { (mm) }\end{array}$ & $\begin{array}{c}\text { Aqueous } \\
\text { fraction } \\
\text { (mm) }\end{array}$ \\
\hline Escherichia coli & - & 2 & 5 & - \\
$\begin{array}{l}\text { Pseudomonas } \\
\text { aeruginosa }\end{array}$ & - & - & 7 & 3 \\
$\begin{array}{l}\text { Staphylococcus } \\
\text { aureus }\end{array}$ & 1 & 2 & 5 & 2 \\
$\begin{array}{l}\text { Salmonella } \\
\text { typhi }\end{array}$ & 1 & 1 & 4 & - \\
\hline
\end{tabular}

The diameter recorded is the diameter of the zone of inhibition less the diameter of the cup $(8 \mathrm{~mm})$.

Values are mean $(n=5)$.

aqueous ethanol extract compared favourably with Gentamycin for the gram-ve and gram+ve organisms employed. The results also indicated that the butanol fraction was the most active.

Another common observable feature in diarrhoea cases is hypermotility of the gut. Reduction of this motility has been achieved by inclusion of anti-spasmodic agents in preparations intended for use in the treatment of diarrhoea. The effects of graded doses of $D$. rotundifolia extract on intestinal transit using freshly prepared charcoal meal was examined using atropine and carbachol as reference drugs (both have known effects on the GI tract). The $\%$ age movement of the charcoal plug was reduced by the extract $(\mathrm{P}<0.05)$ in a dose dependent manner. In the castor oil induced diarrhoea experiment, the extracts exhibited the same characteristics as the reference, Loperamide by non-production of wet faeces. Inhibition of the intestinal motility and non-production wet faeces could be useful actions in the treatment of diarrhoea.

Toxicity potential of a new drug is assessed in the light of the purpose for which it is to be used and the period over which it will be administered. For example, vomiting as a toxic effect will disqualify a drug which is being develop for a minor complaint, but will be accepted in a drug to be used for the treatment of cancer and other life-threatening conditions. Also a toxic

Table 5 Minimum inhibitory concentration MIC $(\mu \mathrm{g} / \mathrm{mL})$ of $D$. rotundifolia leaves

\begin{tabular}{lc}
\hline Test organism & $\begin{array}{c}\text { MIC }(\boldsymbol{\mu g} / \mathbf{m L}) \text { of aq. ethanol extract of } \\
\boldsymbol{D} . \text { Rotundifolia }\end{array}$ \\
\hline Escherichia coli & 50 \\
Pseudomonas & 25 \\
aeruginosa & \\
Staphylococcus & 50 \\
aureus & \\
Salmonella typhi & 50 \\
\hline
\end{tabular}

Values are mean $(n=5)$.
Table 6 Effects of ethanol extract of $D$. rotundifolia on GIT motility

\begin{tabular}{ll}
\hline Group & $\begin{array}{l}\text { \% movement of charcoal } \\
\text { plug (mean } \pm \text { SEM) }\end{array}$ \\
\hline Normal saline & $31.38 \pm 6.03$ \\
$2.5 \mathrm{mg} / \mathrm{kg}$ of Atropine & $25.30 \pm 3.56$ \\
$0.5 \mathrm{mg} / \mathrm{kg}$ of Carbachol & $68.49 \pm 10.34$ \\
$100 \mathrm{mg} / \mathrm{kg}$ of D. rotundifolia & $14.35 \pm 1.10$ \\
$200 \mathrm{mg} / \mathrm{kg}$ of D. rotundifolia & $5.45 \pm 2.99$ \\
$300 \mathrm{mg} / \mathrm{kg}$ of D. rotundifolia & $2.64 \pm 0.35$ \\
$400 \mathrm{mg} / \mathrm{kg}$ of D. rotundifolia & $1.90 \pm 0.20$ \\
\hline
\end{tabular}

Values are mean + SEM $(n=5)$

effect which develops after prolong administration may not disqualify a drug intended for acute condition or for only occasional administration. It has been stated that all substances have potential toxicity and that all herbs can, therefore be harmful, but most would have to be ingested in impossible amounts to cause harm [25].

The primary determinant of the safety of a substance is the dose. The dangers of herbal drug therapy these days are all too often due to lack of stringent assurance rather than to the pharmacological activity of the herbal ingredients themselves. Toxicological studies for all herbal medicines including the determination of their median lethal dose (LD50) and other such parameters essential for a proper dosage are desirable and necessary. If there is the suspected need for more detailed studies, such herbal medicines may be subjected to subacute and chronic toxicity tests.

The purpose of an acute toxicity test is to determine the nature and extent of the adverse reactions to a single dose or an overdose of the drug [25]. Increasing doses of aqueous ethanol extracts of $D$. rotundifolia up to $5 \mathrm{~g} / \mathrm{kg}$ administered to mice per os were not lethal, so that the LD50 could not be determined. It is an indication of the low toxicity of the extracts [21], therefore D. rotundifolia can be said to be relatively safe and may be used for the treatment of diarrhoea. It has been realized that a high degree of precision may not be necessary to compare toxicity [26]. Therefore, the LD50 is now an approximate value estimated from the smallest

Table 7 Effects of ethanol extract of $D$. rotundifolia on Castor oil induced diarrhoea

\begin{tabular}{ll}
\hline Group & Presence of wet faeces \\
\hline Normal saline & + \\
$0.03 \mathrm{mg} / \mathrm{kg}$ of Loperamide & - \\
$100 \mathrm{mg} / \mathrm{kg}$ of $D$. rotundifolia & - \\
$200 \mathrm{mg} / \mathrm{kg}$ of $D$. rotundifolia & - \\
$300 \mathrm{mg} / \mathrm{kg}$ of $D$. rotundifolia & - \\
$400 \mathrm{mg} / \mathrm{kg}$ of $D$. rotundifolia & - \\
\hline
\end{tabular}

Key: - = absence; + = presence 
Table 8 Histological effects of the administration of ethanol extracts of $D$. rotundifolia on rats

\begin{tabular}{|c|c|c|c|c|}
\hline $\begin{array}{l}\text { Dosage of } \\
\text { administration }\end{array}$ & Histological effect on liver tissues & $\begin{array}{l}\text { Histological effect on } \\
\text { kidney tissues }\end{array}$ & $\begin{array}{l}\text { Histological effect } \\
\text { on Heart tissues }\end{array}$ & $\begin{array}{l}\text { Histological effect } \\
\text { on the testes }\end{array}$ \\
\hline $\begin{array}{l}0.9 \mathrm{ml} \text { of } \\
\text { normal saline }\end{array}$ & Tissues appeared normal. No evidence of tissue necrosis & $\begin{array}{l}\text { Tissues appeared normal. } \\
\text { No evidence of tissue } \\
\text { necrosis }\end{array}$ & $\begin{array}{l}\text { Tissues appeared } \\
\text { normal. No evidence } \\
\text { of tissue necrosis }\end{array}$ & $\begin{array}{l}\text { Tissues appeared } \\
\text { normal. No evidence } \\
\text { of tissue necrosis }\end{array}$ \\
\hline $\begin{array}{l}250 \mathrm{mg} / \mathrm{kg} \text { of } \\
\text { D. rotundifolia }\end{array}$ & $\begin{array}{l}\text { Densely stained nuclei, increased congestion of the } \\
\text { vessels, all of which are evidence of tissue necrosis }\end{array}$ & $\begin{array}{l}\text { Tissues appeared normal. } \\
\text { No evidence of tissue } \\
\text { necrosis }\end{array}$ & $\begin{array}{l}\text { Tissues appeared } \\
\text { normal. No evidence } \\
\text { of tissue necrosis }\end{array}$ & $\begin{array}{l}\text { Tissues appeared } \\
\text { normal. No evidence } \\
\text { of tissue necrosis }\end{array}$ \\
\hline $\begin{array}{l}500 \mathrm{mg} / \mathrm{kg} \text { of } \\
\text { D. rotundifolia }\end{array}$ & $\begin{array}{l}\text { There was increased cytoplasmic eosinophilia and } \\
\text { densely stained nuclei. There was also increased } \\
\text { congestion of the vessels. These are evidence of liver } \\
\text { cell damage. }\end{array}$ & $\begin{array}{l}\text { Showed tubular necrosis } \\
\text { and degenerative } \\
\text { changes in the tubules }\end{array}$ & $\begin{array}{l}\text { Tissues appeared } \\
\text { normal. No evidence } \\
\text { of tissue necrosis }\end{array}$ & $\begin{array}{l}\text { Presence of ill } \\
\text { defined testes with } \\
\text { indistinct cell } \\
\text { outlines. }\end{array}$ \\
\hline
\end{tabular}

number of animals possible. The dose is used to calculate the initial dose to be tried in man during the clinical trials. It has been suggested that a simple limit test, aimed at determining the effect on animals, of the largest dose likely to be administered to a human being is often enough [27].

The general purpose of the sub-acute toxicity tests is to determine the organs that are likely to be susceptible to toxicity by the herbal medicines. Histopathological effects of the liver of rats administered $250 \mathrm{mg} / \mathrm{kg}$ and $500 \mathrm{mg} / \mathrm{kg}$ per day of the aqueous ethanol extracts of $D$. rotundifolia showed increased cytoplasmic eosinophilia and densely stained nuclei compared to the control. There was also increased congestion of the vessels. These are evidence of liver cell damage. The kidneys of the rats administered D. rotundifolia showed tubular necrosis and degenerative changes in the tubules. The sections of the hearts administered $D$. rotundifolia and normal saline were not significantly affected. There were no marked adverse alterations or degeneration of tissues since these vital organs showed normal architectures suggesting no morphological disruptions as compared with the control group.

\section{Conclusion}

Herbal medicines can gain the confidence of orthodox health practitioners when there are scientifically established proofs of their claimed efficacies. On the basis of the overall results from our investigations, the use of $D$. rotundifolia in the treatment of diarrhoea, veneral diseases, dysentery and relief of stomach ache is justified. Extracts of $D$. rotundifolia have in this work been found to possess antimicrobial and antispasmodic activities which makes it good candidate for further works in diarrhoea management. It is however advised that herbal practitioners should be aware of the likely effects that may occur, especially on prolonged usage.

\section{Author details}

'Department of Pharmacognosy, Faculty of Pharmacy, University of Benin, Benin City. Nigeria. ${ }^{2}$ Faculty of Pharmacy, University of Benin, Benin City.
Nigeria. ${ }^{3}$ Department of Anatomy, College of Medical Sciences, University of Benin, Benin City. Nigeria.

\section{Authors' contributions}

TA carried out the plant preparations, Antimicrobial and phytochemical investigations, PO carried out the Antidiarrhoea experiments while FA carried out the Toxicity evaluation. All authors read and approved the final manuscript.

\section{Competing interests}

The authors declare that they have no competing interests.

Received: 14 September 2010 Accepted: 17 November 2010

Published: 17 November 2010

\section{References}

1. Srivastera J, Lambert J, Vietweyar N: Medicinal plants: An expanding role in development. World Bank Technical Paper 1996, 320(1).

2. Baurmman RH: Traditional Medicine in Modern Healthcare. World Health Forum 1982, 3(1).

3. Holistic Online. [http://www.holisticonline.com/].

4. Eisenberg DM, Kester RC, Foster C, Norlock FE, Calkins DR, Delbanco TL: Unconventional medicine in the United States: prevalence, costs and patterns of use. N Engl J Med 1993, 328:246-52.

5. Eisenberg DM, Davis RB, Ettner SC, Appel S, Wilkey S, VanRompay M, Kessler R: Trends in alternative medicine use in the United States, 19901997: results of a follow-up survey. JAMA 1998, 280:1569-75.

6. Sofowora A: The state of medicinal plants research in Nigeria. Ibadan University press, Nigeria; 1 1986, 101.

7. Loigier HA: Spermatophyta. Descriptive flora of Puerto Rico and Adjacent Islands 1994, 1:3.

8. Wagner WL, Herbst DR, Sohmer SH: Manual of the flowering plants of Hawaii. University of Hawaii press, Bishop Museum, Honolulu; 1990, 210

9. Gill LS: Ethnomedical uses of plants in Nigeria. University of Benin press; 1992, 103.

10. Botanical description of Dissotis rotundifolia. [http://hear.Org/pier/species/ Dissotis-rotundifolia.asp].

11. Kokwaso JC: Medicinal plants of East Africa. General printers, Nairobi, Kenya; 1976, 198.

12. Noumi $\mathrm{E}$, Yomi A: Medicinal plants used in intestinal diseases in Mbalmayo Region. Fitoterapia 2001, 246-254.

13. Watt JM, Breyer-Brandwijk MG: The medicinal and poisonous plants of Southern and Eastern Africa. E \& S Livingstone Ltd, Edinburgh \& London; 2 1962:137:744.

14. Brain KR, Turner TD: Practical evaluation of Phytopharmaceuticals. WrightScientechnica, Bristol; 1 1975, 144

15. Ciulei I: Methodology for analysis of vegetable drugs. UNIDO Romania $1981,17-25$

16. Harborne JB: Phytochemical methods. A guide to modern technique of plant analysis. Chapman and Hill, London; 1992, 279.

17. Evans WC: Trease and Evans Pharmacognosy. WB Saunders Ltd. London; 14 1996, 119-159. 
18. Onwukaeme ND, Anuforo DC: Phytochemical and Pharmacological studies on Pycanthus angolensis (Welb) Warb (Myristicaceae). Discovery and Innovation 1993, 5:317-322.

19. Izzo AA, Nicoleti M, Giannatassio B, Capasso F: Antidiarrhoeal activity of Terminalia sevicea Burch. Ex. Dc. Extracts. In Natural Drugs and the Digestive tract EMSI, Rome Edited by: Capasso F, Mascolo N 1992, 223-230.

20. Washington JA: In manual of clinical microbiology.Edited by: Lennette $E$, Balowa A, Hausler WJ, Shadomy HJ. American Society of Microbiology, Washinggton DC; 1985:967-970.

21. Dietrich $L: A$ new approach to practical acute toxicity testing. Archives of Toxicology 1983, 54:275-287.

22. Adefemi OA, Elujoba AA, Odesanmi WO: Evaluation of the toxicity potential of Cassia podocarpa with reference to official Senna. West Afr Journal of Pharmacol and Drug Res 1988, 8:41-48.

23. Obasi NB, Igboechi AC, Anuforo DC: Studies of the antidiarrhoeal potentials of some compositae plants. Medicinal plants in a developing economy. Proceedings of a workshop organized by the Nigerian Society of Nigeria 1990, 108-116.

24. Abere TA, Agoreyo FO: Antimicrobial and toxicological evaluation of the leaves of Baissea axillaries Hua used in the management of HIV/AIDS patients. BMC Complement Altern Med 2006, 6:22.

25. Klein R: Toxicology and herbs. Aust Journal of Med Herbalism 1996, 8:100-110.

26. Akubue PI: Textbook of Pharmacology. African First Publishers Limited ${ }_{i} 1$ 2006, 30-31.

27. Malmfors T, Teiling A: LD 50 : Its value for the pharmaceutical industry in safety evaluation of drugs. Acta Pharmacol Toxicol 1983, 52(Suppl 2):229.

\section{Pre-publication history}

The pre-publication history for this paper can be accessed here: http://www.biomedcentral.com/1472-6882/10/71/prepub

doi:10.1186/1472-6882-10-71

Cite this article as: Abere et al:: Antidiarrhoea and toxicological evaluation of the leaf extract of Dissotis rotundifolia triana (Melastomataceae). BMC Complementary and Alternative Medicine 2010 10:71.

\section{Submit your next manuscript to BioMed Central and take full advantage of:}

- Convenient online submission

- Thorough peer review

- No space constraints or color figure charges

- Immediate publication on acceptance

- Inclusion in PubMed, CAS, Scopus and Google Scholar

- Research which is freely available for redistribution 